\title{
Presynaptically expressed long-term depression at cerebellar parallel fiber synapses
}

\author{
De-lai Qiu • Thomas Knöpfel
}

Received: 24 May 2008 /Revised: 27 June 2008 / Accepted: 7 July 2008 / Published online: 29 July 2008

(C) The Author(s) 2008

\begin{abstract}
Plasticity at synapses between parallel fiber (PF) and Purkinje neurons (PN) is widely accepted as a cellular model for certain forms of cerebellar learning. Although PF-PN synapses are known to express bidirectional longterm plasticity at the postsynaptic site, long-term plasticity at the presynaptic site is currently limited to potentiation of the synapses. In this paper, we report on presynaptically expressed PF long-term depression (preLTD) that is observed when presynaptically expressed PF long-term potentiation (preLTP) is pharmacologically prevented. PF preLTD is most efficiently induced by $4 \mathrm{~Hz} \mathrm{PF}$ stimulation and requires activation of cannabinoid $\mathrm{CB} 1$ receptors. Our results indicate that, during preLTD induction, endocannabinoids are released in an NMDA receptor-dependent, but not mGlu1 receptor-dependent, fashion. We conclude that bidirectional plasticity mechanisms exist for both presynaptic and postsynaptic components of cerebellar learning.
\end{abstract}

Keywords Cerebellar parallel fiber P Purkinje neuron . GCaMP2 transgenic mouse - Calcium transients .

Presynaptic LTD · Cannabinoid CB1 receptor

\section{Introduction}

The Marr-Albus model of cerebellar function was among the first to postulate variable synaptic weights in a concrete

\author{
D.-1. Qiu · T. Knöpfel ( $\bowtie)$ \\ Laboratory for Neuronal Circuit Dynamics, \\ RIKEN Brain Science Institute, \\ 2-1 Hirosawa, Wako-shi, \\ Saitama 351-0198, Japan \\ e-mail: tknopfel@brain.riken.jp
}

synaptic pathway (the parallel fiber-Purkinje neuron $[\mathrm{PF}-$ $\mathrm{PN}$ ] synapse) as a way to implement a specific memory function, cerebellar learning [2, 29]. Subsequent theoretical and experimental work demonstrated that efficient synaptic weight-based memory storage requires bidirectional learning rules $[5,28]$. The PF-PN synapse has been a powerful system to explore many of these predictions. The first form of PF-PN long-term plasticity to be described on the basis of experimental data was "cerebellar LTD" that is based on a heterosynaptic mechanism (conjunctive climbing fiber and PF activity) and that is expressed as a reduced postsynaptic response to synaptically released PF transmitter $[19,20,25]$. In line with the theoretical quest to identify bidirectional plasticity mechanisms, postsynaptic expression of PF-PN LTP was discovered and characterized [11, 23, 24]. Presynaptic expression of PF-PN LTP (preLTP) had already been demonstrated some years before [38]. We recently provided evidence for an NMDA-NO pathway in preLTP that suggested a heterosynaptic mechanism with activation of interneurons [33]. However, the complementing LTD at the presynaptic site (preLTD) has, to date, remained elusive.

In this paper, we describe and characterize preLTD. We used optical recordings of PF presynaptic calcium transients in combination with electrophysiological methods to directly assess the presynaptic expression and mechanism of preLTD. PreLTD can be efficiently induced with $4 \mathrm{~Hz} P F$ stimulation and is prevented by an endocannabinoid CB1 receptor antagonist. Along with our recent results on preLTP [33], a scheme emerges where the induction of presynaptic PF-PN plasticity is mediated by humoral factors (endocannabinoids and NO) that may be released from molecular layer interneurons. 


\section{Experimental methods}

Slice preparation

All experimental procedures were conducted in line with the RIKEN guidelines and were approved by the RIKEN Animal Experiments Committee and RIKEN Safety Center. Cerebellar slices were prepared from adult (4-6 weeks old) transgenic mice expressing the fluorescent protein calcium sensor GCaMP2 [13, 14] or from standard laboratory ICR mice. Animals were deeply anesthetized with halothane and decapitated. The cerebellum was dissected and placed in ice-cold artificial cerebrospinal fluid (ACSF) containing (in $\mathrm{mM}$ ): $125 \mathrm{NaCl}, 3 \mathrm{KCl}, 1 \mathrm{MgSO}_{4}, 2 \mathrm{CaCl}_{2}, 1 \mathrm{NaH}_{2} \mathrm{PO}_{4}, 25$ $\mathrm{NaHCO}_{3}$, and 10 D-glucose bubbled with $95 \% \mathrm{O}_{2} / 5 \% \mathrm{CO}_{2}$ ( $\mathrm{pH} 7.4,295-305 \mathrm{mOsm}$ ). The cerebellar cortex was glued onto a block of $3 \%$ agar. The agar block with the cerebellar cortex was trimmed and glued to the stage of a Vibratome (VT 1000s, Leica, Nussloch, Germany) so that the cerebellar cortex was cut in the frontal plane (coronal slices, $300 \mu \mathrm{m}$ thick). The slices were incubated for $\geq 1 \mathrm{~h}$ in a chamber filled with $95 \% \mathrm{O}_{2} / 5 \% \mathrm{CO}_{2}$ equilibrated ACSF at room temperature $\left(24-25^{\circ} \mathrm{C}\right)$ prior to recording.

Imaging and electrophysiology

For calcium imaging, slices were submerged in a perfused recording chamber mounted below epifluorescence optics consisting of a $\times 10$ water-immersion objective $(\mathrm{NA}=0.3$; Nikon Microscope, Japan) and a $\times 1$ projection lens (Leica Microsystems, Germany). The fluorescence excitation was delivered using a halogen lamp (Moritex, Japan) and a 470to 490-nm excitation filter. Fluorescence light was filtered through a 505-nm dichroic mirror and a 520- to 540-nm band-pass filter. Images were acquired by a cooled chargecoupled device system (Sensicam; PCO Computer Optics, Germany) at a frame rate of $40 \mathrm{~Hz}$ for sweeps of $2 \mathrm{~s}$. Data were recorded with macros under Image Pro (Media Cybernetics, Silver Spring, MD, USA) and with synchronized illumination control and stimulation via a Master 8 controller (A.M.P.I., Jerusalem, Israel). Color-coded maps of $\Delta F / F$ were obtained using custom-made macros under Image Pro (Media Cybernetic, Silver Spring, MD, USA). The time course of fluorescence bleaching was estimated using fluorescence measurements from nonresponsive areas or sweeps without stimulation. Fluorescence traces were divided by the normalized bleaching curve. Background fluorescence (e.g., fluorescence from parallel fibers below the stimulated parallel fibers) was not subtracted. For electrical stimulation, current pulses $(200 \mu \mathrm{s}, 10-100 \mu \mathrm{A})$ at $0.033 \mathrm{~Hz}$ (Figs. 3, 4, 5, 6, and 7) or $0.05 \mathrm{~Hz}$ (Figs. 1 and 8 ) were delivered through a glass electrode mounted on a remote-controlled manipulator (Luigs and Neumann, Ger-

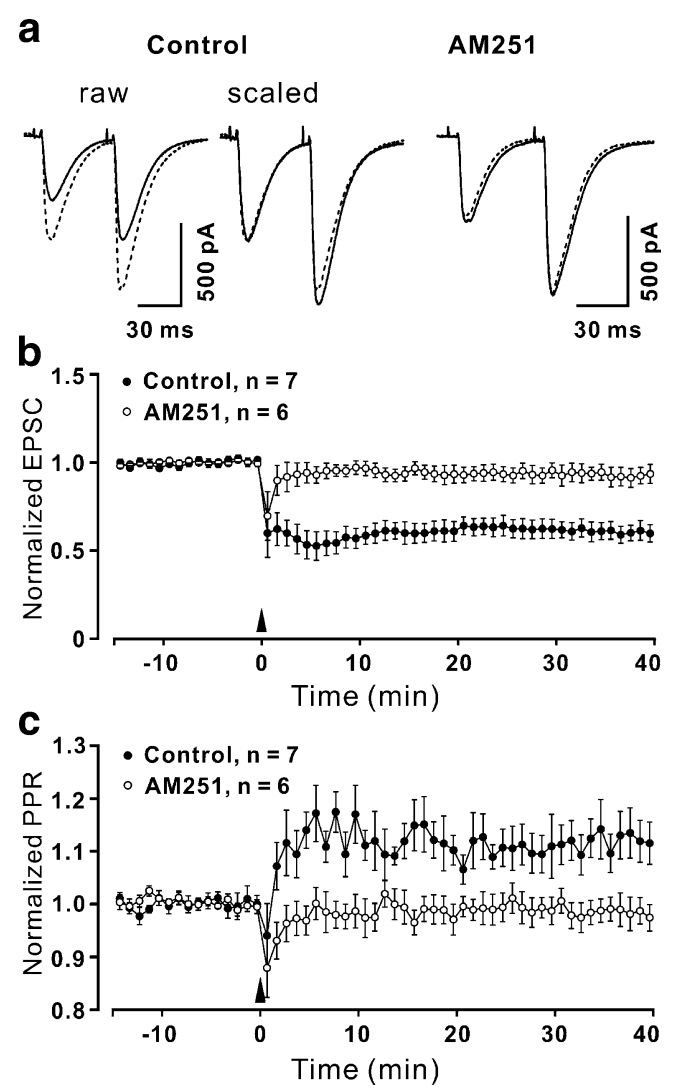

Fig. $14 \mathrm{~Hz}$ parallel fiber stimulation induced LTD at parallel fiberPurkinje cell synapses: increase in PPR and requirement for activation of CB1 receptors. a Representative examples of EPSCs elicited by paired-pulse stimulation in the presence of $10 \mu \mathrm{M} \mathrm{H}-89,10 \mu \mathrm{M} \mathrm{L}$ NNA (control), and with additional $5 \mu \mathrm{M}$ AM251 before (dashed lines) and after (solid lines) $4 \mathrm{~Hz}$ stimulation. Each trace is an average of three pairs of EPSCs to two PF stimuli delivered $50 \mathrm{~ms}$ apart. Time course of mean EPSC amplitude (b) and PPR (c) of experiments in which the $4-\mathrm{Hz}$ stimulation induction protocol was delivered under control conditions (filled circles, $n=7$ ) and in the presence of AM251 (open circles, $n=6$ ). Error bars indicate $\pm \mathrm{SEM}$

many). The stimulating electrode containing ACSF (0.1$0.5 \mathrm{M} \Omega$ ) was placed in the molecular layer of the cerebellar cortex for PF stimulation. Whole-cell patch clamp recordings from PN somata in coronal slices were performed on a standard fixed-stage microscope (Nikon Microscope, Japan) employing a $\times 60$ water-immersion objective and DIC optics (Nikon Microscope, Japan). Patch electrodes (2$4 \mathrm{M} \Omega$ ) contained a solution of the following composition (in mM); BAPTA $\left(\mathrm{K}_{4}{ }^{+}\right.$salt) 30 , HEPES $10, \mathrm{CaCl}_{2} 15, \mathrm{KCl}$ 5, $\mathrm{MgCl} 3.5, \mathrm{NaCl} 4$, sucrose 35, $\mathrm{Na}_{2}$ ATP 4, and $\mathrm{Na}_{2} \mathrm{GTP}$ 0.4 (pH 7.3 with $\mathrm{KOH}$, osmolarity adjusted to $300 \mathrm{mOsm}$ ). Cells were held in voltage clamp mode at $-70 \mathrm{mV}$. Series resistance was monitored by applying voltage pulses $(10 \mathrm{~ms}, 5 \mathrm{mV})$, and only cells with stable series resistance were included in the analysis. The LTD induction protocol was applied at least 30 min after establishing the whole-cell configuration in order to allow sufficient time for the diffusion of BAPTA into the dendritic tree. The ACSF 
included picrotoxin $(50 \mu \mathrm{M})$ during all recordings to prevent inhibitory synaptic transmission. Values are expressed as the mean \pm SEM; nonparametric statistics (Mann-Whitney $U$ test) determined the level of statistical significance between groups of data.

\section{Chemicals}

Reagents included picrotoxin, (2S)-3-[[(1S)-1-(3,4-dichlorophenyl)ethyl]amino-2-hydroxypropyl] (phenylmethyl) phosphinic acid (CGP), (RS)- $\alpha$-cyclopropyl-4-phosphonophenylglycine (CPPG), D-aminophosphonovaleric acid (DAPV), JNJ16259685 (JNJ), $N^{\mathrm{G}}$-nitro-L-arginine(L-NNA), $N$-[2-( $p$-bromocinnamylamino)ethyl]-5-isoquinoline sulfonamide (H-89), $N$-(piperidin-1-yl)-5-(4-iodophenyl)-1-(2,4di-chlorophenyl)-4-methyl-1H-pyrazole-3-carboxamide (AM251), and (R)-(+)-[2,3-dihydro-5-methyl-3-(4-morpholinylmethyl)pyrrolo[1,2,3-de]-1,4-benzoxazin-6-yl]-1naphthalenylmethanone mesylate (WIN55,212-2). 6aR, 10aR)-3-(1-Methanesulfonylamino-4-hexyn-6-yl)-6a,7,10,10atetrahydro-6,6,9-trimethyl-6H-dibenzo[b,d]pyran (O-2050).

All drugs were purchased from Tocris Cookson (Bristol, UK), except picrotoxin (Sigma-Aldrich, Japan) and H-89 (LC Laboratories, Woburn, MA, USA).

\section{Results}

$4 \mathrm{~Hz}$ stimulation induced a CB1 receptor-dependent LTD at PF-PN synapses

We recently reported that stimulation of PFs with 120 pulses at $4 \mathrm{~Hz}$ induces LTP of presynaptic PF $\mathrm{Ca}^{2+}$ transients (preLTP) and LTP of PF to PN synaptic transmission. We found that preLTP is protein kinase A (PKA)-dependent and requires the activation of an NMDA/ nitric oxide (NO) pathway [33]. In the course of this previous study, we noted that after the prevention of LTP by the PKA inhibitor $\mathrm{H}-89,4 \mathrm{~Hz}$ stimulation caused a persistent depression of $\mathrm{PF} \mathrm{Ca}^{2+}$ transients (preLTD). In the present study, we characterize this novel form of PF LTD.

Because the observations made in Qiu and Knöpfel [33] were based on recordings made in mice that express the calcium sensor GCaMP2 in their parallel fibers, it could be argued that the presence of the calcium sensor may have altered PF calcium dynamics and plasticity. Paired-pulse ratio (PPR) at PF-PN synapses is a sensitive indicator of presynaptic calcium dynamics and its alteration by exogenous $\mathrm{Ca}^{2+}$ buffers [3] but did not differ between wild-type (WT) and GCaMP2 mice (PPR at $50 \mathrm{~ms}$ interpulse interval, $\mathrm{WT}=2.11 \pm 0.07, n=14 ; \quad \mathrm{GCaMP} 2=2.01 \pm 0.09, n=7, \quad p=$ $0.4)$ [33]. We, therefore, concluded that calcium dynamics are not adversely affected by the presence of GCaMP2 in our mice. To exclude the possibility that the expression of preLTD is in any other way related to the presence of the fluorescent calcium sensor protein and to confirm that the LTD of presynaptic $\mathrm{Ca}^{2+}$ transients translates into a LTD of PF-PN synaptic transmission under conditions where postsynaptic mechanisms of PF plasticity are clearly absent, we used standard intracellular patch clamp recording techniques in cerebellar slices prepared from WT mice. To efficiently prevent preLTP and postsynaptically expressed plasticity, recordings were performed in the presence of $\mathrm{H}$ $89(10 \mu \mathrm{M})$ and L-NNA $(10 \mu \mathrm{M})$ in the extracellular solution and an intracellular solution that contained $30 \mathrm{mM}$ BAPTA.

Under these conditions, $4 \mathrm{~Hz}$ stimulation reliably induced LTD of PF EPSCs $(60.2 \pm 5.0 \%$ of baseline at $40 \mathrm{~min}$ after $4 \mathrm{~Hz}$ stimulation, $p=0.001, n=7$; Fig. 1a,b) and an increase in PPR $(111.9 \pm 4.9 \%$ of baseline; last 5 min, $p=0.024$ vs. baseline, $n=7$; Fig. $1 \mathrm{a}, \mathrm{c}$ ).

The amount of LTD of PF EPSCs reported in this study in the presence of $10 \mu \mathrm{M} \mathrm{H}-89$ and $10 \mu \mathrm{M}$ L-NNA in the extracellular solution and $30 \mathrm{mM}$ BAPTA in the intracellular solution is larger than the LTD initially observed in the presence of only $10 \mu \mathrm{M}$ H-89 [33]. This observation indicates that LTP at the PF-PN synapse is more efficiently prevented in the presence of both $10 \mu \mathrm{M} \mathrm{H}-89$ and $10 \mu \mathrm{M}$ L-NNA instead of $10 \mu \mathrm{M} \mathrm{H}-89$ only. We did not investigate higher concentrations of $\mathrm{H}-89$ to test if a more complete inhibition of PKA occludes the additional effect of L-NNA because with increasing concentration unspecific actions of $\mathrm{H}-89$ become increasingly problematic. In addition, more efficient buffering of postsynaptic $\mathrm{Ca}^{2+}$ more efficiently depressed any effects that are mediated by $\mathrm{Ca}^{2+}$-dependent postsynaptic mechanism and that may have limited the amount of LTD initially observed.

Parallel fibers express the endocannabinoid receptor CB1, and its activation mediates short-term plasticity at synapses onto PN and stellate cells [7, 18, 22]. It has been reported that production of endocannabinoids in PNs is required for cerebellar PF-PN postsynaptic LTD [36]. We examined whether $\mathrm{CB} 1$ receptors are involved in preLTD. Depression of EPSCs and increase in PPR did not occur in the presence of an antagonist at endocannabinoid $\mathrm{CB} 1$ receptors, $5 \mu \mathrm{M}$ AM251 $(\mathrm{EPSC}=93.6 \pm 5.4 \%$ of baseline at $40 \mathrm{~min}$ after $4 \mathrm{~Hz}$ stimulation, unchanged from baseline, $p=0.31, n=6$; Fig. 1a,b; PPR $=98.1 \pm 2.7 \%$ of baseline; last 5 min, unchanged from baseline, $p=0.384, n=6$; Fig. 1a,c).

Long-lasting depression of PF calcium transients

The increase in PPR following the induction of LTD at the PF-PN synapses by $4 \mathrm{~Hz}$ PF stimulation points toward a presynaptic expression mechanism. To directly monitor 
presynaptic mechanisms, we used a line of transgenic mice that selectively express the fluorescent protein calcium indicator GCaMP2 in cerebellar PFs [13, 14, 33]. In these mice, the indicator protein is not expressed in any other cellular element of the molecular layer, including Purkinje cells, molecular layer interneurons, and glial cells [13, 14]. Stimuli applied to the cerebellar molecular layer of slices prepared from these GCaMP2 mice induced fluorescence transients within a bundle of PFs that were not affected by antagonists of AMPA, NMDA, or mGlu1 glutamate receptors $[13,14]$. They were, however, abolished by the removal of extracellular calcium [33] and strongly attenuated during application of the $\mathrm{GABA}_{\mathrm{B}}$ receptor agonist baclofen $(10 \mu \mathrm{M}$; Fig. 2). Hence, we demonstrated that these fluorescence transients represent PF presynaptic $\mathrm{Ca}^{2+}$ signals.

Stimulation of PFs with 120 pulses at $4 \mathrm{~Hz}$ induces LTP of presynaptic $\mathrm{PF} \mathrm{Ca}^{2+}$ transients (preLTP) and LTP of PF to PN synaptic transmission [33]. To prevent the induction of preLTP, all $\mathrm{Ca}^{2+}$ imaging experiments were performed in the presence of H-89 except for the experiments where we demonstrate that preLTD can also be uncovered by blocking NO synthase (NOS).

Single test pulses were delivered to the molecular layer at a frequency of $0.033 \mathrm{~Hz}$ to induce $\mathrm{Ca}^{2+}$ transients within a bundle of PFs (Fig. 3a). After 30 min of baseline recordings, $\mathrm{PF}$ were stimulated with 120 pulses delivered at $4 \mathrm{~Hz}$ and then the test stimulation was resumed. The $4-\mathrm{Hz} \mathrm{PF}$ stimulation (in the presence of $\mathrm{H}-89$ ) induced a long-lasting a

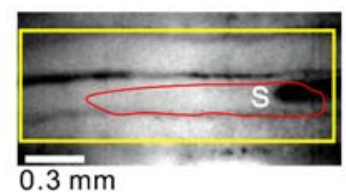

b

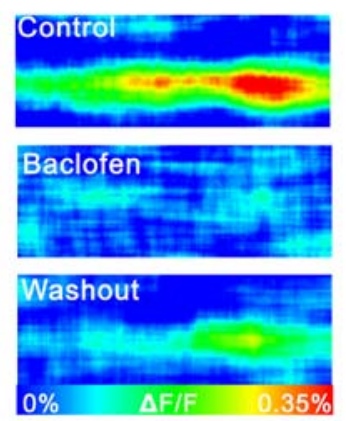

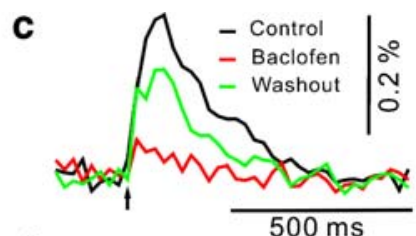

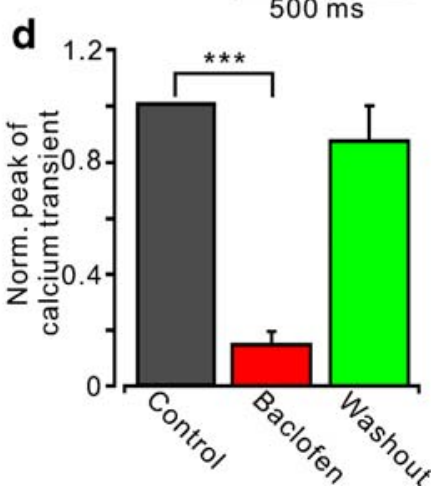

Fig. 2 Parallel fiber $\mathrm{Ca}^{2+}$ transients monitored by the fluorescent protein calcium sensor GCaMP2. a Fluorescent image of a coronal cerebellar slice from a GCaMP2 mouse with stimulation electrode $(S)$ placed in the molecular layer. b Color-coded map of peak $\mathrm{Ca}^{2+}$ transients in response to a single $\mathrm{PF}$ stimulation pulse in normal ACSF, $10 \mu \mathrm{M}$ baclofen, and washout. $\mathbf{c}$ Time course of $\Delta F / F$ values obtained from responsive area (outline shown in a). d Mean baselinenormalized $\Delta F / F$ values in normal ACSF, $10 \mu \mathrm{M}$ baclofen, and washout $\left({ }^{*} p<0.001, n=4\right.$, paired $t$ test) a1 Pre 1 Pre 2 Pre 3 Post 1 Post 2 Post 3 Post 4 $\int_{0.3 \mathrm{~mm}} \int_{0}(2)$

a2

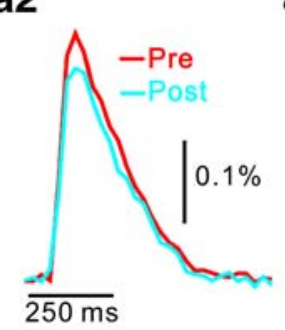

a3

b

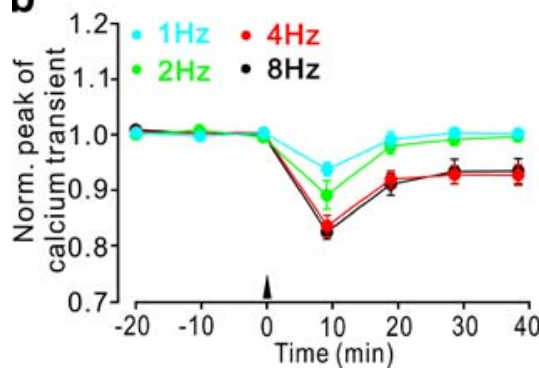

C

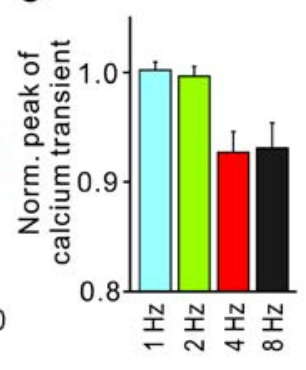

Fig. 3 Long-term depression of parallel fiber presynaptic $\mathrm{Ca}^{2+}$ transients induced by $4 \mathrm{~Hz}$ parallel fiber stimulation. a $1-34 \mathrm{~Hz} \mathrm{PF}$ stimulation in the presence of $\mathrm{H}-89$ induced a long-term depression of $\mathrm{PF} \mathrm{Ca}{ }^{2+}$ transients. 1 Left, fluorescent image of a coronal cerebellar slice from a GCaMP2 transgenic mouse with stimulation electrode $(S)$ placed in the molecular layer. Yellow rectangle indicates cropped region used for color-coded maps of peak $\mathrm{Ca}^{2+}$ transients in response to a single PF stimulation pulse, before (Pre1-Pre3) and after (Post1Post4) LTD induction (arrowhead). 2 Time course of PF $\mathrm{Ca}^{2+}$ transients obtained from responsive area (red outline in 1). 3 Time course of the baseline-normalized peak amplitude of $\mathrm{Ca}^{2+}$ transient from the experiment illustrated in 1 and 2 . b Time course of the baseline-normalized mean peak amplitude of $\mathrm{PF} \mathrm{Ca}^{2+}$ transient before and after delivery of 120 pulses to the PFs at $1 \mathrm{~Hz}(n=7), 2 \mathrm{~Hz}(n=7)$, $4 \mathrm{~Hz}(n=8)$, and $8 \mathrm{~Hz}(n=8)$. Note that LTD was induced with $4-8 \mathrm{~Hz}$ PF stimulation but not with $1-2 \mathrm{~Hz}$ stimulation. c Mean baselinenormalized $\mathrm{PF} \mathrm{Ca}{ }^{2+}$ transient $40 \mathrm{~min}$ after $\mathrm{PF}$ stimulation at $1-8 \mathrm{~Hz}$. All experiments were conducted in the presence of $10 \mu \mathrm{M} \mathrm{H}-89$. Data points in $\mathbf{b}$ and $\mathbf{c}$ are presented as the mean \pm SEM

depression of $\mathrm{PF} \mathrm{Ca}^{2+}$ transients (at $40 \mathrm{~min}$ after $4 \mathrm{~Hz}$ stimulation, $92.7 \pm 1.9 \%$ of baseline, $p=0.007$; Fig. 3a $1-$ $3, \mathrm{~b})$. H-89 is a potent inhibitor of PKA but it is known that this substance also has non-PKA-mediated effects on several other kinase- and voltage-gated ion channels $[12,31,41]$ that may lead to a misinterpretation of its effects described in this study. To confirm that the long-lasting depression of $\mathrm{PF} \mathrm{Ca}^{2+}$ transients is uncovered by preventing preLTP and not by some PKA-independent side effects, we examined whether the long-lasting depression of $\mathrm{PF} \mathrm{Ca}^{2+}$ transients could be 
induced when preLTP was instead prevented by blockade of NOS. The long-lasting depression of $\mathrm{PF} \mathrm{Ca}^{2+}$ transients was also observed when induction of preLTP was prevented by the NOS inhibitor L-NNA $(100 \mu \mathrm{M})$ instead of H-89 (at $40 \mathrm{~min}$ after $4 \mathrm{~Hz}$ stimulation, $92.4 \pm 1.6 \%$ of baseline, $p=$ $0.003, n=9$, data not illustrated). These results indicate that long-lasting depression of $\mathrm{PF} \mathrm{Ca}^{2+}$ transients can be observed when preLTP is blocked.

Since this was the first indication that preLTD was possible at this synapse, we sought to establish the optimal induction protocol. First, we varied the stimulation frequency during induction (120 pulses delivered at 1, 2, 4, and $8 \mathrm{~Hz}$ ). While $1-2 \mathrm{~Hz}$ stimulation did not induce a longlasting depression of $\mathrm{PF} \mathrm{Ca}^{2+}$ transients, stimulations at either 4 or $8 \mathrm{~Hz}$ were similarly effective to trigger the longlasting depression of $\mathrm{PF} \mathrm{Ca}^{2+}$ transients (Fig. 3b,c). Notably, the same frequency dependence was previously revealed for preLTP [33] Secondly, we determined the number of stimulation pulses that is sufficient to induce a saturating amount of the long-lasting depression of $\mathrm{PF} \mathrm{Ca}^{2+}$ transients. We, therefore, varied the number of PF stimulation pulses delivered at $4 \mathrm{~Hz}$ and found that 30 or 60 pulses did not induce the long-lasting depression of $\mathrm{PF}$ $\mathrm{Ca}^{2+}$ transients while 120,240 , and 480 pulses induced similar amounts of the long-lasting depression of $\mathrm{PF} \mathrm{Ca}^{2+}$ transients (Fig. 4a). Finally, we varied the temporal patterns at which 120 pulses were delivered to PFs. Delivery of four pulses at $20 \mathrm{~Hz}$ repeated 30 times at $1 \mathrm{~Hz}$ or two pulses at $20 \mathrm{~Hz}$ repeated 60 times at $2 \mathrm{~Hz}$ did not induce a longlasting depression of $\mathrm{PF} \mathrm{Ca}^{2+}$ transients. Conversely, protocols that delivered two pulses at $20 \mathrm{~Hz}$ repeated 60 times at $4 \mathrm{~Hz}$ and one pulse repeated 120 times at $4 \mathrm{~Hz}$ efficiently induced a long-lasting depression of $\mathrm{PF} \mathrm{Ca}^{2+}$ transients (Fig. 4b). Given the robust nature of the standard 120pulses $/ 4 \mathrm{~Hz}$ stimulation pattern for induction of the long-lasting depression of $\mathrm{PF} \mathrm{Ca}^{2+}$ transients, we conducted all subsequent experiments using this protocol.

Long-lasting depression of $\mathrm{PF} \mathrm{Ca}^{2+}$ transients did not require mGlu4 or $\mathrm{GABA}_{\mathrm{B}}$ receptor activation or NO

$\mathrm{GABA}_{\mathrm{B}}$ and mGlu4 receptors are expressed at PF presynaptic sites where they control the release of glutamate [15, 30]. The expression of preLTD could be caused by a persistent modification of the activity of these presynaptic receptors. To test whether blockade of mGlu4 receptors or $\mathrm{GABA}_{\mathrm{B}}$ receptors could prevent preLTD, we used the specific mGlu4 and $\mathrm{GABA}_{\mathrm{B}}$ receptor antagonists CPPG $(10 \mu \mathrm{M})$ and CGP $(10 \mu \mathrm{M})$. In the presence of either antagonist, the long-lasting depression of $\mathrm{PF} \mathrm{Ca}^{2+}$ transients was not significantly different from controls (at 40 min after $4 \mathrm{~Hz}$ stimulation: CPPG versus control, $p=$ a1

a2

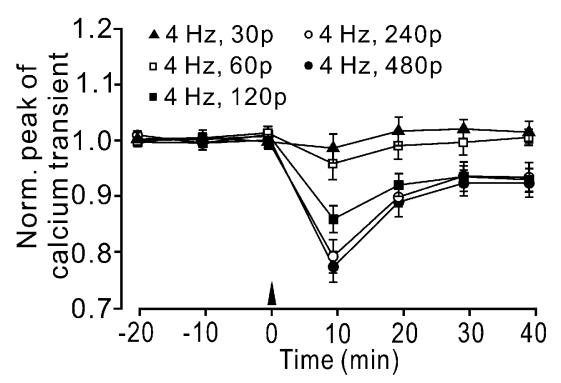

b1

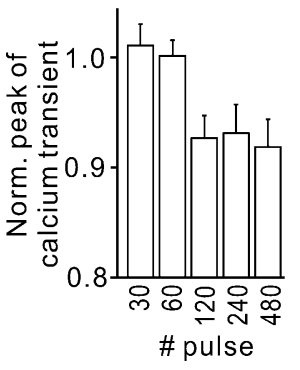

b2
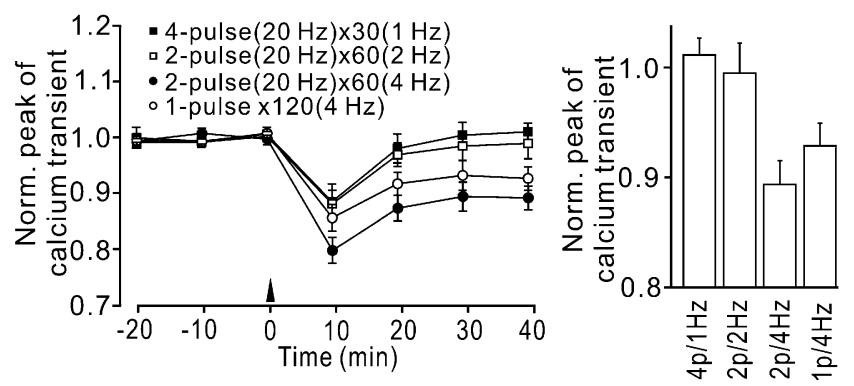

Fig. 4 Stimulation pulse number and pattern requirement for induction of LTD of parallel fiber presynaptic $\mathrm{Ca}^{2+}$ transients. a 1 Time course of the baseline-normalized peak amplitude of $\mathrm{PF} \mathrm{Ca}^{2+}$ transient before and after delivery of $30(n=4), 60(n=6), 120(n=7)$, $240(n=6)$, and $480(n=5)$ PF pulses at $4 \mathrm{~Hz}$. Note that 120 pulses were required and sufficient for maximal LTD induction. a 2 Mean baseline-normalized $\mathrm{PF} \mathrm{Ca}^{2+}$ transient 40 min after $\mathrm{PF}$ stimulation with 30 to 480 pulses at $4 \mathrm{~Hz}$. b 1 and 2 Exploration of burst stimulation protocols for LTD induction. 1 Time course of the baseline-normalized peak amplitude of $\mathrm{PF} \mathrm{Ca}^{2+}$ transient before and after delivery of four pulses at $20 \mathrm{~Hz}$ repeated 30 times at $1 \mathrm{~Hz}(n=5)$, two pulses at $20 \mathrm{~Hz}$ repeated 60 times at $2 \mathrm{~Hz}(n=5)$, two pulses at $20 \mathrm{~Hz}$ repeated 60 times at $4 \mathrm{~Hz}(n=5)$, and one pulse repeated 120 times at $1 \mathrm{~Hz}(n=7) .2$ Mean baseline-normalized $\mathrm{PF} \mathrm{Ca}^{2+}$ transient 40 min after PF stimulation with 120 pulses at different patterns. All experiments were conducted in the presence of $10 \mu \mathrm{M} \mathrm{H}-89$. Data points in $\mathbf{a}$ and $\mathbf{b}$ are presented as the mean \pm SEM

0.882, $n=9$; Fig. 5a; CGP versus control, $p=0.84, n=8$; Fig. 5b,d). Induction of preLTP requires NO [33]. To test whether there is a corresponding requirement of $\mathrm{NO}$ for the long-lasting depression of $\mathrm{PF} \mathrm{Ca}^{2+}$ transients, we tested $4 \mathrm{~Hz}$ stimulation in the presence of an inhibitor of NOS, LNNA. As shown in Fig. 5c, L-NNA $(10 \mu \mathrm{M})$ did not prevent the induction of the long-lasting depression of $\mathrm{PF}$ $\mathrm{Ca}^{2+}$ transients $(90.3 \pm 1.8 \%$ of baseline at $40 \mathrm{~min}$ after $4 \mathrm{~Hz}$ stimulation, $p=0.001, n=8$ ). On the contrary, the amount of the long-lasting depression of $\mathrm{PF} \mathrm{Ca}^{2+}$ transients observed in the presence of $100 \mu \mathrm{M}$ L-NNA was significantly larger than that of the controls $(87.1 \pm 1.8 \%$ of baseline at $40 \mathrm{~min}$ after stimulation, $p=0.049, n=5$; Fig. $5 \mathrm{c}$,d). This observation correlates well with the observations made with intracellular recordings that revealed a larger preLTD when L-NNA was applied on top of H-89 (compare Figs. 1 and 7 in [33]). 

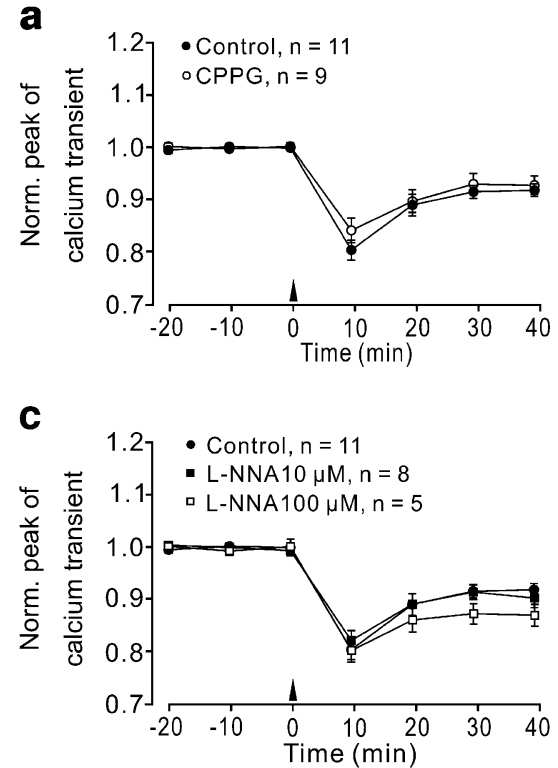

Fig. 5 PF presynaptic LTD does not require mGlu4 or $\mathrm{GABA}_{\mathrm{B}}$ receptor activation or NO. LTD of the $\mathrm{PF} \mathrm{Ca}^{2+}$ transients was not prevented by the mGlu4 receptor antagonist CPPG (a) or by the $\mathrm{GABA}_{\mathrm{B}}$ receptor antagonist CGP (b). c Blockade of nitric oxide synthase (L-NNA; $10 \mu \mathrm{M}$ and $100 \mu \mathrm{M}$ ) did not prevent induction of

Induction of the long-lasting depression of $\mathrm{PF} \mathrm{Ca}^{2+}$ transients required the activation of $\mathrm{CB} 1$ receptors and was mimicked by a $\mathrm{CB} 1$ agonist

Blockade of endocannabinoid CB1 receptors with $5 \mu \mathrm{M}$ AM251 completely prevented the induction of preLTD $(105.1 \pm 2.3 \%$ of baseline at $40 \mathrm{~min}$ after stimulation, $p=$ $0.195, n=8$; Fig. 6 a). To test if CB1 receptor activation is sufficient to trigger preLTD, we tested the effect of bath application of the CB1 agonist, WIN55212-2 (2 $\mu \mathrm{M})$. WIN55212-2 robustly reduced $\mathrm{PF} \mathrm{Ca}^{2+}$ transients, a reduction that persisted after washout of WIN55212-2 and even after subsequent addition of the CB1 receptor antagonist (Fig. 6b). As an additional control experiment, we first applied AM251 $(5 \mu \mathrm{M})$ and added WIN55212-2, as above, 40 min thereafter. In the presence of AM251, WIN55212-2 did not induce any depression of PF $\mathrm{Ca}^{2+}$ transients $(102.5 \pm 2.9 \%$ of baseline at $40 \mathrm{~min}$ after application of WIN55212-2, $p=0.699, n=6$; Fig. 6b), demonstrating that AM251 efficiently blocks the action of WIN55212-2 at the concentrations employed.

It is known that AM251 blocks the constitutive activity of CB1 receptors ("inverse agonist") and, therefore, it is not unexpected that the application of AM251 causes some increase of the PF calcium transients, by itself (c.f. Fig. 6a, b). This effect cannot, of course, explain the depression of the calcium transient after $4 \mathrm{~Hz}$ stimulation. However, it may be argued that the constitutive activity of the CB1 receptor rather than its activation is required for the
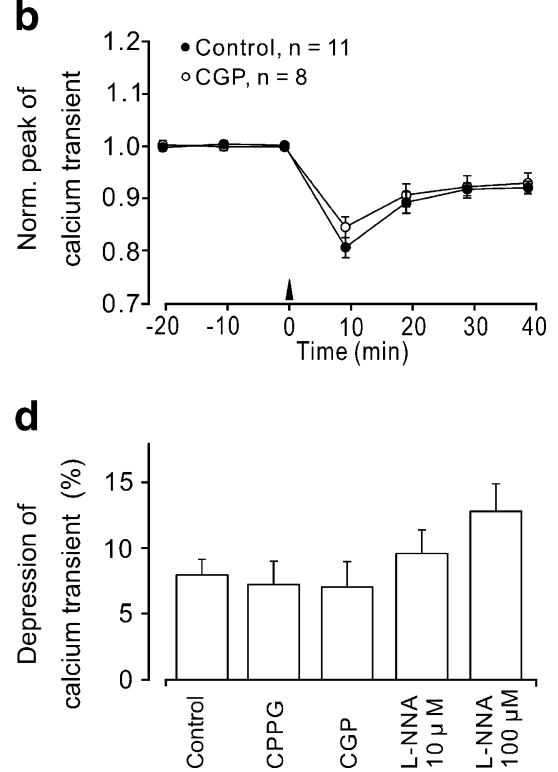

LTD. Note enhanced amount of LTD in the presence of $100 \mu \mathrm{M} \mathrm{L}$ NNA. Controls in $\mathbf{a}, \mathbf{b}$, and $\mathbf{c}$ are from the same interlaced experiments. d Mean depression of PF calcium transients in the presence of antagonists. All experiments were conducted in the presence of $10 \mu \mathrm{M} \mathrm{H}-89$. Data points are presented as the mean $\pm \mathrm{SEM}$

induction or expression of PF-PN preLTD. To test for this possibility, we used the neutral $\mathrm{CB} 1$ receptor antagonist $\mathrm{O}-$ 2050 [8]. Blockade of endocannabinoid CB1 receptors with $10 \mu \mathrm{M}$ O-2050 prevented induction of preLTD (control= $88.3 \pm 3.5 \%$ of baseline at $40 \mathrm{~min}$ after stimulation; $\mathrm{O}-2050=$ $103.6 \pm 3.7 \%$ of baseline at $40 \mathrm{~min}$ after stimulation, $p=0.012$ vs. control, $n=9$; Fig. $6 \mathrm{c}$ ).

After the persistent WIN55212-2-induced depression of PF Ca ${ }^{2+}$ transients, $4 \mathrm{~Hz}$ PF stimulation did not lead to any further depression (Fig. 6d). Occlusion of the electrically induced preLTD by the CB1 agonist-induced persistent depression of $\mathrm{PF} \mathrm{Ca}^{2+}$ transients strongly suggested overlapping transduction pathways and demonstrated that the activation of CB1 receptors was sufficient to induce a longlasting depression of $\mathrm{PF} \mathrm{Ca}^{2+}$ transients (that is, stimulation of coincident PFs was not required). We conclude that CB1 receptor activation is both necessary and sufficient to induce a long-lasting depression of $\mathrm{PF} \mathrm{Ca}^{2+}$ transients.

Long-lasting depression of $\mathrm{PF} \mathrm{Ca}{ }^{2+}$ transients was prevented by blockade of NMDA but not mGlu1 receptors

Where is the source of the endocannabinoids for the induction of this preLTD? PNs are known to generate and release endocannabinoids [7], and more recently, molecular layer interneurons (stellate and basket cells) were shown to release endocannabinoids following PF stimulation [6, 37]. In contrast to the synaptically induced endocannabinoid release by PNs that specifically requires the activation of 


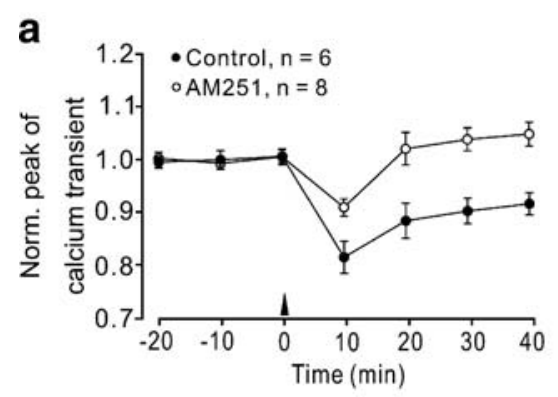

C

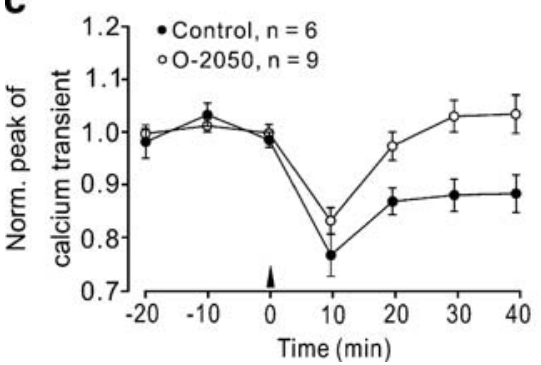

Fig. 6 PF presynaptic LTD required the activation of $\mathrm{CB} 1$ receptors and is induced by the application of a CB1 agonist. a LTD of the PF $\mathrm{Ca}^{2+}$ transients was prevented by the CB1 receptor antagonist AM251 $(5 \mu \mathrm{M})$. b Bath application of the CB1 agonist WIN55212-2 $(2 \mu \mathrm{M}$, $10 \mathrm{~min}$ ) induced a depression of $\mathrm{PF} \mathrm{Ca}^{2+}$ transient that outlasted agonist application (filled circles,WIN55212-2, $n=6$ ) and persisted when the CB1 antagonist AM251 was applied after WIN55212-2 (open circles, WIN55212-2 $\rightarrow$ AM251, $n=6$ ). WIN55212-2 was

mGlu1 receptors [7], release from molecular layer interneurons is efficiently triggered by NMDA receptor activation and also, but less so, by mGlu1 receptor activation [6]. We found that the NMDA receptor antagonist D-APV prevented the long-lasting depression of $\mathrm{PF} \mathrm{Ca}^{2+}$ transients $(100.1 \pm 1.5 \%$ of baseline at $40 \mathrm{~min}$ after stimulation, $p=$ $0.805, n=7$; Fig. $7 \mathrm{a}$ ), whereas $4 \mathrm{~Hz}$ stimulation in the presence of the mGlul receptor antagonist JNJ16259685 still induced a long-lasting depression of $\mathrm{PF} \mathrm{Ca}^{2+}$ transients $(94.5 \pm 3.1 \%$ of baseline at $40 \mathrm{~min}$ after stimulation, $p=$ 0.026; not different from the control, $p=0.62 ; n=7$; Fig. 7b). These results indicate that the long-lasting depression of $\mathrm{PF} \mathrm{Ca}^{2+}$ transients is NMDA receptordependent but mGlu1 receptor-independent and point toward interneurons as the source of the endocannabinoids.

Intracellular recordings from PNs demonstrated that preLTD was prevented by blockade of NMDA but not mGlu1 receptors

As described above, the long-lasting depression of $\mathrm{PF} \mathrm{Ca}^{2+}$ transients was prevented by blockade of NMDA but not of mGlu1 receptors. It may be argued that these pharmacological effects may not be reflected when assessing LTD by intracellular recordings. To account for this conjecture, we performed intracellular recordings as described above.
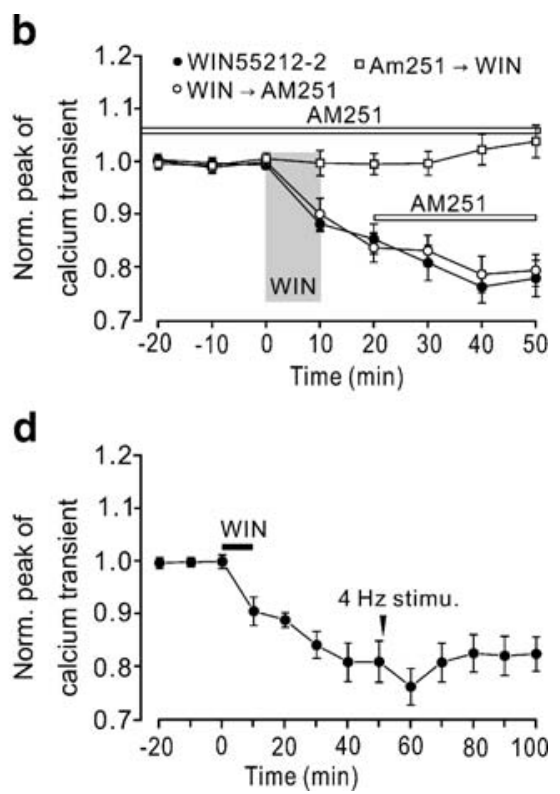

ineffective when the $\mathrm{CB} 1$ antagonist AM251 was applied before WIN55212-2 (open squares, AM251 $\rightarrow$ WIN55212-2, $n=6$ ). $\mathbf{c}$ LTD of the $\mathrm{PF} \mathrm{Ca}{ }^{2+}$ transients was prevented by the neutral $\mathrm{CB} 1$ receptor antagonist O-2050 $(10 \mu \mathrm{M})$. d WIN-induced depression of PF $\mathrm{Ca}^{2+}$ transients was not augmented by subsequent $4 \mathrm{~Hz}$ PF stimulation $(n=$ 6). All experiments were conducted in the presence of $10 \mu \mathrm{M} \mathrm{H}-89$. Data points are presented as the mean \pm SEM

In this set of experiments, $4 \mathrm{~Hz}$ stimulation under control conditions induced LTD of PF EPSCs $(64.3 \pm 7.5 \%$ of baseline at $40 \mathrm{~min}$ after $4 \mathrm{~Hz}$ stimulation, $p=0.007, n=7$; Fig. $8 \mathrm{a}, \mathrm{b})$ and an increase in PPR $(114.0 \pm 6.1 \%$ of baseline, last 5 min, $p=0.01, n=7$; Fig. 8a 3). Depression of EPSCs and increase in PPR did not occur in the presence of $50 \mu \mathrm{M}$ APV (EPSC $=95.8 \pm 8.6 \%$ of baseline at $40 \mathrm{~min}$ after $4 \mathrm{~Hz}$ stimulation, unchanged from baseline, $p=0.278, n=9$; Fig. $8 \mathrm{a} 2$; PPR $=98.4 \pm 4.2 \%$ of baseline, last $5 \mathrm{~min}$, unchanged from baseline, $p=0.905, n=9$; Fig. 8a 3). However, depression of EPSCs and increase in PPR was not different from controls when the mGlul receptor antagonist JNJ16259685 was applied to the bath solution (EPSC $=56.6 \pm 6.9 \%$ of baseline at $40 \mathrm{~min}$ after $4 \mathrm{~Hz}$ stimulation, $p=0.408$ vs. control, $n=9$; Fig. 8 b 2 ; PPR $=$ $109.8 \pm 5.0 \%$ of baseline, last $5 \mathrm{~min}, p=0.837$ vs. control, $n=$ 9; Fig. 8b 3).

These results confirm that LTD monitored by intracellular recordings from voltage-clamped Purkinje cells is also blocked by APV and is insensitive to mGlu1 receptor blockade.

\section{Discussion}

The main result from this study is that $4 \mathrm{~Hz} \mathrm{PF}$ stimulation can induce LTD of $\mathrm{PF} \mathrm{Ca}^{2+}$ transients and of PF-PN 

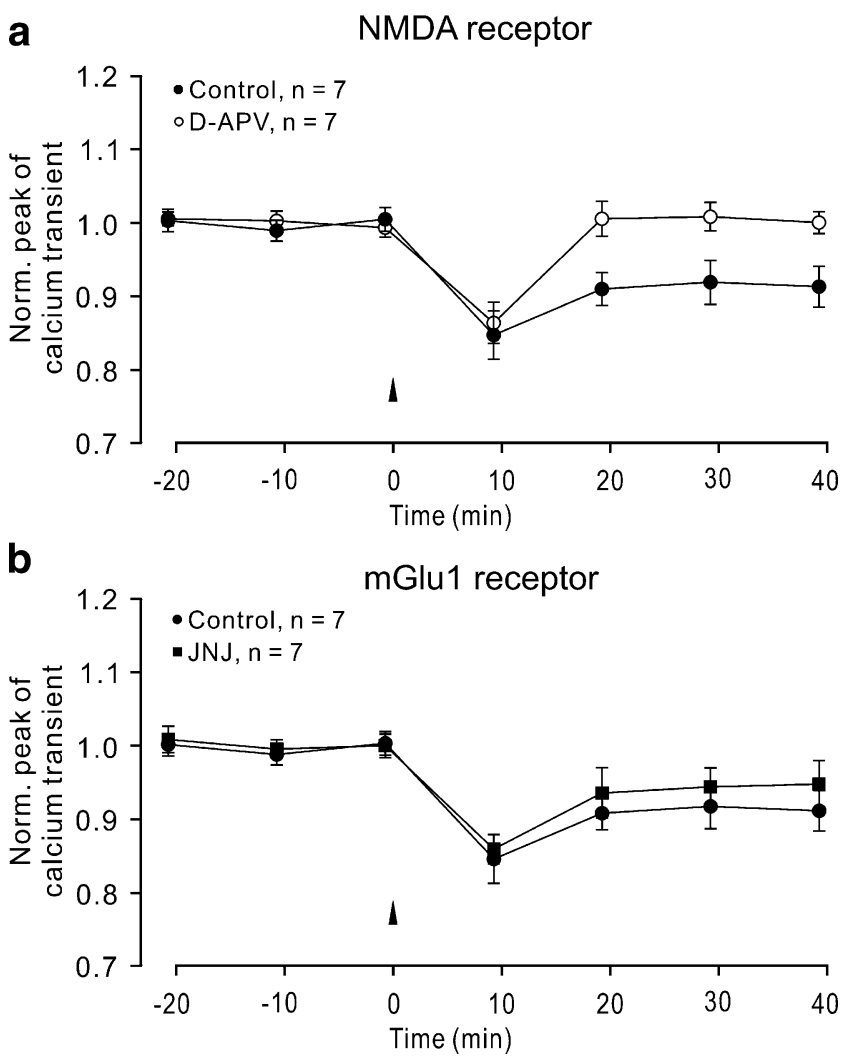

Fig. 7 LTD of PF calcium transients is prevented by an NMDA receptor antagonist but not by an mGlu1 receptor antagonist. a LTD of the $\mathrm{PF} \mathrm{Ca}^{2+}$ transients was prevented by the NMDA receptor antagonist D-APV $(50 \mu \mathrm{M})$. b In the presence of the mGlu1 receptor antagonist JNJ $(1 \mu \mathrm{M})$, LTD of the PF $\mathrm{Ca}^{2+}$ transients was still observed after $4 \mathrm{~Hz}$ PF stimulation. Error bars indicate \pm SEM

EPSCs via the activation of $\mathrm{CB} 1$ receptors. This is the first analysis of presynaptically expressed LTD at PF-PN synapses. Together with previous findings that identified presynaptically expressed presynaptic LTP at this synapse, this study firmly establishes a bidirectional presynaptic plasticity mechanism at PF synapses.

\section{Methodological considerations}

Our study takes advantage of transgenic mice that express the fluorescent calcium indicator in cerebellar granule cells, including parallel fibers. The expression pattern of the sensor protein together with the pharmacological properties of fluorescence transients obtained upon stimulation PF demonstrated that they report $\mathrm{PF} \mathrm{Ca}^{2+}$ transients. These transients have slower kinetics than the actual (volumeaveraged) PF calcium transients because of reporter kinetics [42] and not because of adverse slice conditions as GCaMP2 signals with comparable kinetics have been observed in PFs of living mice [14]. Furthermore, the expression level of GCaMP is low enough as to not buffer the $\mathrm{PF} \mathrm{Ca}^{2+}$ transients to a functionally significant degree because significant $\mathrm{Ca}^{2+}$ buffering affects PF PPR, and this parameter did not differ between control and GCaMP2 mice. We confirmed the main conclusion of this study using conventional patch clamp techniques in WT mice (Figs. 1 and 8 ). In the present study, we demonstrated preLTD of EPSCs in WT mice while our preceding report on preLTP included a set of experiments that showed preLTD simultaneously monitored as depression of $\mathrm{PF} \mathrm{Ca}^{2+}$ transients and EPSCs (Fig. 7 in [33]) in slices prepared from GCaMP2 mice. Thus, the preLTD of EPSCs reported in this study in nontransgenic mice also occurred in slices prepared from GCaMP2 mice. Finally, we confirmed the main pharmacological properties of directly (presynaptically) monitored preLTD (CB1 and NMDA receptor dependence, lack of requirement of mGlu1 receptors) using standard intracellular recording techniques.

\section{Demonstration of preLTD}

PreLTD has not been characterized before. The best explanation as to why this form of plasticity has been elusive up until now is that preLTP is induced with a largely overlapping induction protocol. Only when we pharmacologically prevented preLTP induction did we uncover preLTD. It should be mentioned that, in previous studies designed to test the importance of PKA in preLTP, preLTD was not highlighted $[26,27]$ with the exception of a note in our recent study of preLTP [33]. However, the work of Linden and coworkers used cultured cerebellar cells where the action of diffusible messengers such as the endocannabinoids could significantly differ from that seen in acute slice preparations. In our previous study, we observed a small but significant depression of PF-PN EPSCs following $4 \mathrm{~Hz}$ PF stimulation in the presence of $\mathrm{H}-$ 89 [33]. The intracellular recordings performed in the present study were designed to further minimize any preLTP or postsynaptic plasticity (extracellular H-89 plus L-NNA to prevent preLTP and $30 \mathrm{mM}$ BAPTA to prevent postsynaptic plasticity). Under these conditions, not only did we observe LTD of PF-PN EPSCs but this was accompanied by a clear increase in PPR. The increase in PPR is consistent with the more direct evidence provided by the LTD of the presynaptic $\mathrm{Ca}^{2+}$ transients to establish a presynaptic expression locus of this form of PF-PN plasticity.

The role of endocannabinoids in cerebellar plasticity

Endocannabinoid receptor-dependent forms of presynaptic LTD exist outside the cerebellum $[10,17,35,40]$, and endocannabinoids are well-described in mediating shortterm plasticity in the cerebellum $[6,7,22]$. In contrast to the form of LTD described in this study, these CB1 
Fig. 8 Intracellularly recorded $4 \mathrm{~Hz}$ PF-PN LTD also required the activation of NMDA but not of mGlul receptors. a 1 Representative examples of EPSCs elicited by paired-pulse stimulation in control conditions and in the presence of $50 \mu \mathrm{M}$ DAPV before (solid lines) and after (dashed lines) $4 \mathrm{~Hz}$ stimulation. Each trace is an average of three pairs of EPSCs to two PF stimuli delivered $50 \mathrm{~ms}$ apart. a 2 Summary of the experiments in which the $4 \mathrm{~Hz}$ stimulation induction protocol was delivered under control conditions (filled circles, $n=7$ ) and in the presence of $50 \mu \mathrm{M}$ DAPV (open circles, $n=9$ ). a 3 Time course of mean PPR (second $\mathrm{EPSC} /$ first EPSC, normalized to baseline levels). b 1-3 Same as a $1-3$ except that control conditions (filled circles, $n=7$ ) were compared with recordings in the presence of $1 \mu \mathrm{M}$ JNJ16259685 (open cirles, $n=9$ ). Data points are presented as the mean \pm SEM a1

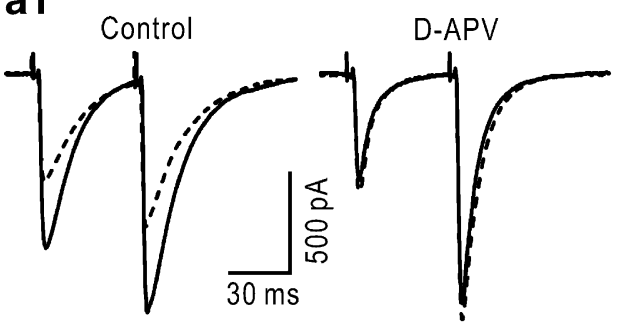

b1

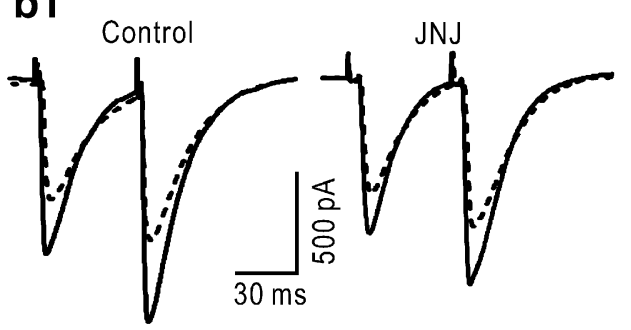

a2

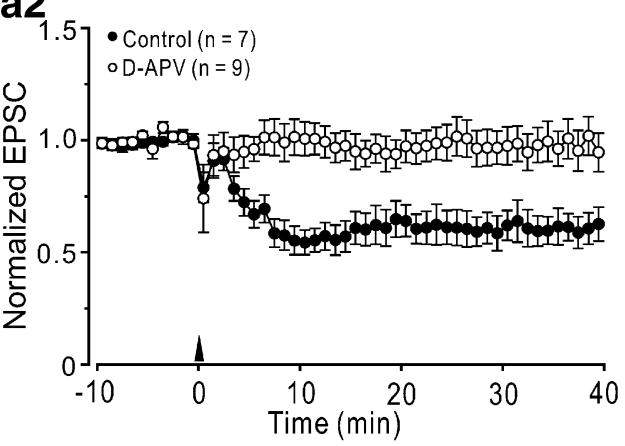

b2
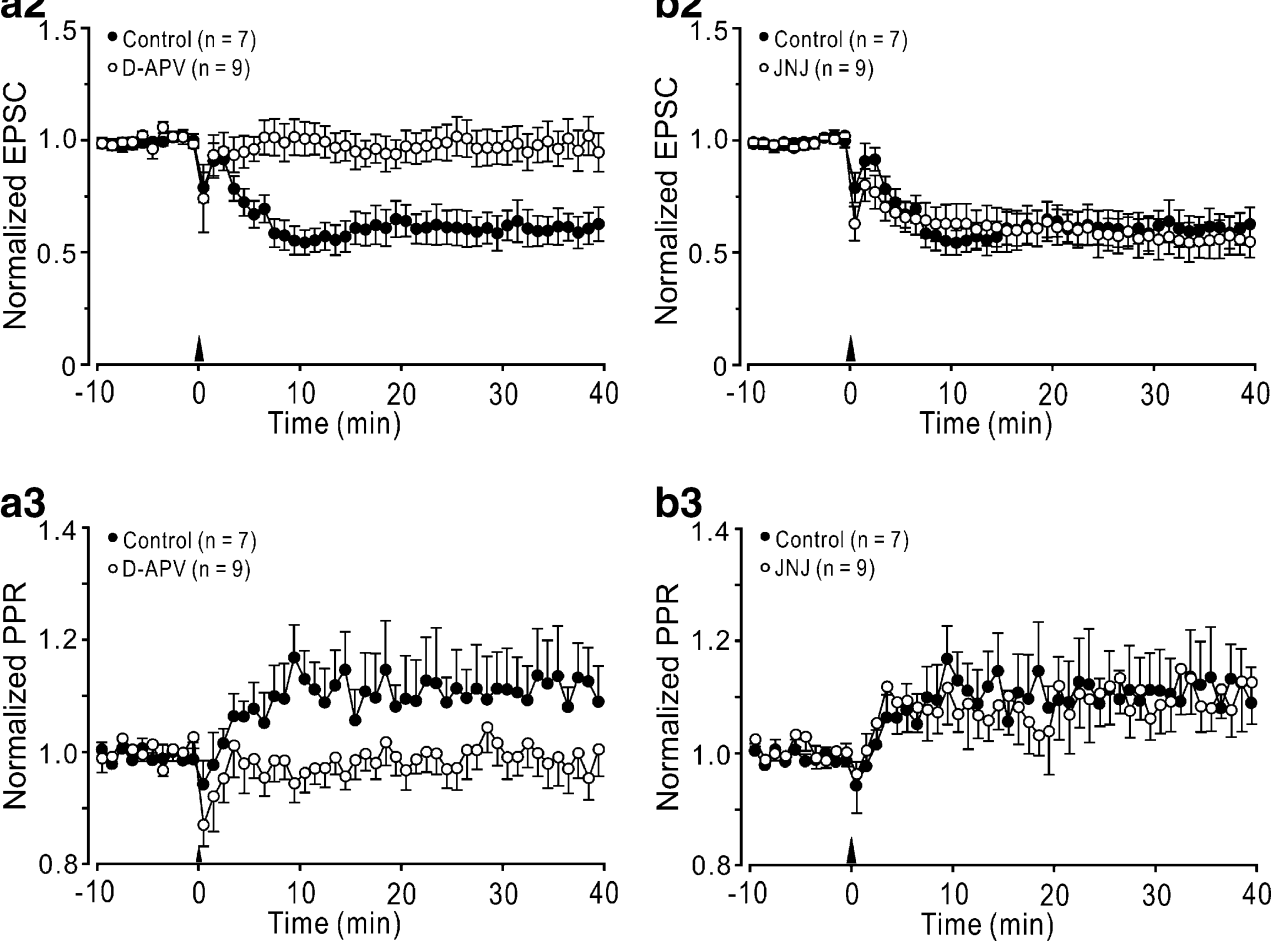

b3

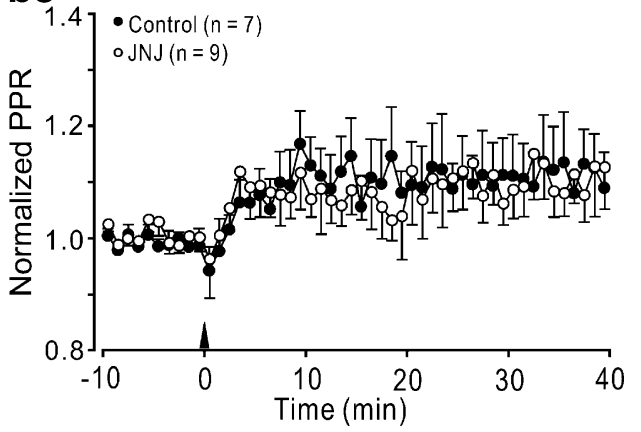

receptor-mediated effects on $\mathrm{PF}-\mathrm{PN}$ synaptic transmission are short-lived.

The role of endocannabinoids in PF long-term plasticity had been less clear. It has been shown that climbing fiberevoked endocannabinoid signaling can suppress PF presynaptic LTP [43]. Regehr and coworkers found that CB1 receptor activation did not cause persistent modification of presynaptic PF mechanisms but proposed that $\mathrm{CB} 1$ receptors control the expression of postsynaptic PF-PN LTD [6, 36]. Their inference that endocannabinoids only affected postsynaptic PF-PN LTD was based on the assumption that there is only a postsynaptic form of LTD at this synapse and indirect evidence derived from the lack of change in PPR. Consistent with their results, we obtained only a small, statistically nonsignificant increase in PPR when preLTD was induced in slices without efficient block of preLTP [33], while preLTD with a clear increase in PPR was observed in the presence of a mixture of NOS and PKA inhibitors (Fig. 1). Safo and Regehr [36] reported that the effects of WIN55212-2 on PF to PN synaptic transmission was fully reversible upon application of AM251, while we found that AM251 (at a concentration effective to block the effect of WIN55212-2) did not reverse the WIN55212-2induced depression of PF calcium transients. The reason for this discrepancy is unclear.

More similar to our results, a presynaptically expressed form of endocannabinoid-dependent LTD has been suggested at parallel fiber to stellate cell synapses [37]. Our results, based on a direct assessment of $\mathrm{PF}$ presynaptic $\mathrm{Ca}^{2+}$ transients, are consistent with the conclusion of the latter study.

The role of NMDA receptors in cerebellar plasticity

NMDA receptor activation does not contribute to $\mathrm{PF}$ presynaptic $\mathrm{Ca}^{2+}$ transients either during single or repetitive PF stimulation [13, 33, 39]. However, NMDA receptor activation was required for the long-lasting depression of PF $\mathrm{Ca}^{2+}$ transients and preLTD induction (Figs. 7 and 8a). Given that Purkinje cells are thought to express relatively low amounts of functional NMDA receptors [4, 21] and that only CF but not PF stimulation could induce an 
NMDA receptor current in PNs of adult rodents [32, 34], while molecular layer interneurons are known for a rich expression of NMDA receptors [1,9], we propose that interneurons are the most likely source of NO for preLTP $[33,39]$ and of endocannabinoids [6] for pre LTD. Of course, we cannot exclude that $4 \mathrm{~Hz} \mathrm{PF}$ stimulation also activates NMDA and/or mGlu1 receptors on PNs to some degree resulting in some release of endocannabinoids. If the LTD observed in PNs that were patch-clamped with a high concentration of a $\mathrm{Ca}^{2+}$ chelator (30 mM BAPTA) in the intracellular solution (Figs. 1 and 8 ) was mediated by the release of endocannabinoids from PNs, one has to assume that this hypothetical release is $\mathrm{Ca}^{2+}$-independent or that neighboring PNs were the source of the endocannabinoid that triggered plasticity at the synapse of the patch-clamped PN. Also, preLTD did not require the pathway that involves mGlul receptors (that dominates over the NMDA receptor pathway in PNs; see [6]) because preLTD was observed in the presence of an mGlu1 receptor antagonist (Figs. $7 \mathrm{~b}$ and $8 \mathrm{~b}$ ).

The role of diffusible messengers in cerebellar plasticity

Our identification and characterization of preLTD together with our previous characterization of preLTP demonstrates that synaptic strength at the PF-PN synapse is bidirectionally plastic. Whereas postsynaptic PF-PN bidirectional plasticity relies on the activation pattern or strength of the input, in this study, it is the transduction pathway that defines the direction of the change of synaptic strength. It is the release and action of either NO (for LTP) or endocannabinoids (for LTD) that determines the direction of the change in synaptic efficacy. Endocannabinoids are unlikely to be released from $\mathrm{PF}$ and our previous results suggested that the NO implicated in preLTP is released from other cellular elements such as molecular layer interneurons. Since endocannabinoids and NO are both diffusible messengers, they can exert their actions beyond the spatial scale of single synapses (a situation that is often referred to as "volume transmission" [16] and, for this reason, we propose the term "volume plasticity" to describe this bidirectional presynaptic PF plasticity). Since volume plasticity will influence all synapses (of a given kind) within reach of the diffusible messenger, it could specifically affect localized representations (e.g., somatotopic maps) and local processing tasks ("microzone processing").

Acknowledgements We thank the members of the Knöpfel laboratory and Dr. Ruth Empson for the helpful discussions. We state the involvement of a series of anonymous reviewers in forming the logic in the presentation of this work. This work was funded by the RIKEN Brain Science Institute.
Open Access This article is distributed under the terms of the Creative Commons Attribution Noncommercial License which permits any noncommercial use, distribution, and reproduction in any medium, provided the original author(s) and source are credited.

\section{References}

1. Akazawa C, Shigemoto R, Bessho Y, Nakanishi S, Mizuno N (1994) Differential expression of five $N$-methyl-D-aspartate receptor subunit mRNAs in the cerebellum of developing and adult rats. J Comp Neurol 347:150-160

2. Albus JS (1971) A theory of cerebellar function. Math Biosci 10:25-61

3. Atluri PP, Regehr WG (1996) Determinants of the time course of facilitation at the granule cell to Purkinje cell synapse. J Neurosci 16:5661-5671

4. Audinat E, Knöpfel T, Gahwiler BH (1990) Responses to excitatory amino acids of Purkinje cells' and neurones of the deep nuclei in cerebellar slice cultures. J Physiol 430:297-313

5. Bear MF (2003) Bidirectional synaptic plasticity: from theory to reality. Philos Trans R Soc Lond B Biol Sci 358:649-655

6. Beierlein M, Regehr WG (2006) Local interneurons regulate synaptic strength by retrograde release of endocannabinoids. J Neurosci 26:9935-9943

7. Brown SP, Brenowitz SD, Regehr WG (2003) Brief presynaptic bursts evoke synapse-specific retrograde inhibition mediated by endogenous cannabinoids. Nat Neurosci 6:1048-1057

8. Canals M, Milligan G (2008) Constitutive activity of the cannabinoid $\mathrm{CB} 1$ receptor regulates the function of co-expressed Mu opioid receptors. J Biol Chem 283:11424-11434

9. Carter AG, Regehr WG (2000) Prolonged synaptic currents and glutamate spillover at the parallel fiber to stellate cell synapse. J Neurosci 20:4423-4434

10. Chevaleyre V, Takahashi KA, Castillo PE (2006) Endocannabinoidmediated synaptic plasticity in the CNS. Annu Rev Neurosci 29:37-76

11. Coesmans M, Weber JT, De Zeeuw CI, Hansel C (2004) Bidirectional parallel fiber plasticity in the cerebellum under climbing fiber control. Neuron 44:691-700

12. Davies SP, Reddy H, Caivano M, Cohen P (2000) Specificity and mechanism of action of some commonly used protein kinase inhibitors. Biochem J 351:95-105

13. Diez-Garcia J, Matsushita S, Mutoh H, Nakai J, Ohkura M, Yokoyama J, Dimitrov D, Knöpfel T (2005) Activation of cerebellar parallel fibers monitored in transgenic mice expressing a fluorescent $\mathrm{Ca}^{2+}$ indicator protein. Eur J Neurosci 22:627-635

14. Diez-Garcia J, Akemann W, Knöpfel T (2006) In vivo calcium imaging from genetically specified target cells in mouse cerebellum. NeuroImage 34:859-869

15. Dittman JS, Regehr WG (1997) Mechanism and kinetics of heterosynaptic depression at a cerebellar synapse. J Neurosci 17:9048-905

16. Fuxe K, Agnati L (1991) Volume transmission in the brain: new aspects for electrical and chemical communications. Raven, New York

17. Gerdeman GL, Ronesi J, Lovinger DM (2002) Postsynaptic endocannabinoid release is critical to long-term depression in the striatum. Nat Neurosci 5:446-451

18. Herkenham M (1992) Cannabinoid receptor localization in brain: relationship to motor and reward systems. Ann NY Acad Sci 654:19-32 
19. Ito M (2001) Cerebellar long-term depression: characterization, signal transduction, and functional roles. Physiol Rev 81: $1143-1195$

20. Ito M, Kano M (1982) Long-lasting depression of parallel fiberPurkinje cell transmission induced by conjunctive stimulation of parallel fibers and climbing fibers in the cerebellar cortex. Neurosci Lett 33:253-258

21. Kakegawa W, Tsuzuki K, Iino M, Ozawa S (2003) Functional NMDA receptor channels generated by NMDAR2B gene transfer in rat cerebellar Purkinje cells. Eur J Neurosci 17:887-891

22. Kreitzer AC, Regehr WG (2001) Cerebellar depolarizationinduced suppression of inhibition is mediated by endogenous cannabinoids. J Neurosci 21:1-5 RC174

23. Lev-Ram V, Wong ST, Storm DR, Tsien RY (2002) A new form of cerebellar long-term potentiation is postsynaptic and depends on nitric oxide but not cAMP. Proc Natl Acad Sci U S A 99: 8389-8393

24. Lev-Ram V, Mehta SB, Kleinfeld D, Tsien RY (2003) Reversing cerebellar long-term depression. Proc Natl Acad Sci U S A 100:15989-15993

25. Linden DJ, Dickinson MH, Smeyne M, Connor JA (1991) A long-term depression of AMPA currents in cultured cerebellar Purkinje neurons. Neuron 7:81-89

26. Linden DJ, Ahn S (1999) Activation of presynaptic cAMPdependent protein kinase is required for induction of cerebellar long-term potentiation. J Neurosci 19:10221-10227

27. Lonart G, Schoch S, Kaeser PS, Larkin CJ, Sudhof TC (2003) Phosphorylation of RIM1alpha by PKA triggers presynaptic longterm potentiation at cerebellar parallel fiber synapses. Cell 115:49-60

28. Mauk MD, Donegan NH (1997) A model of Pavlovian eyelid conditioning based on the synaptic organization of the cerebellum. Learn Mem 4:130-158

29. Marr D (1969) A theory of cerebellar cortex. J Physiol 202:437-470

30. Mateos JM, Azkue J, Sarría R, Kuhn R, Grandes P, Knöpfel T (1998) Localization of the mGlu4a metabotropic glutamate receptor in rat cerebellar cortex. Histochem Cell Biol 109: 135-139

31. Niisato N, Ito Y, Marunaka Y (1999) Effects of PKA inhibitors, $\mathrm{H}$-compounds, on epithelial $\mathrm{Na}^{+}$channels via PKA-independent mechanisms. Life Sci 65:PL109-PL114
32. Piochon C, Irinopoulou T, Brusciano D, Bailly Y, Mariani J, Levenes C (2007) NMDA receptor contribution to the climbing fiber response in the adult mouse Purkinje cell. J Neurosci 27:10797-10809

33. Qiu DL, Knopfel T (2007) An NMDA receptor/nitric oxide cascade in presynaptic parallel fiber-Purkinje neuron long-term potentiation. J Neurosci 27:3408-3415

34. Renzi M, Farrant M, Cull-Candy SG (2007) Climbing-fibre activation of NMDA receptors in Purkinje cells of adult mice. $\mathrm{J}$ Physiol 585:91-101

35. Robbe D, Kopf M, Remaury A, Bockaert J, Manzoni OJ (2002) Endogenous cannabinoids mediate long-term synaptic depression in the nucleus accumbens. Proc Natl Acad Sci U S A 99:8384-8388

36. Safo PK, Regehr WG (2005) Endocannabinoids control the induction of cerebellar LTD. Neuron 48:647-659

37. Soler-Llavina GJ, Sabatini BL (2006) Synapse-specific plasticity and compartmentalized signaling in cerebellar stellate cells. Nat Neurosci 9:798-806

38. Salin PA, Malenka RC, Nicoll RA (1996) Cyclic AMP mediates a presynaptic form of LTP at cerebellar parallel fiber synapses. Neuron 16:797-803

39. Shin JH, Linden DJ (2005) An NMDA receptor/nitric oxide cascade is involved in cerebellar LTD but is not localized to the parallel fiber terminal. J Neurophysiol 94:4281-4289

40. Sjostrom P, Turrigiano GG, Nelson SB (2003) Neocortical LTD via coincident activation of presynaptic NMDA and cannabinoid receptors. Neuron 39:641-654

41. Sun Park W, Kyoung Son Y, Kim N, Boum Youm J, Joo H, Warda M, Ko JH, Earm YE, Han J (2006) The protein kinase inhibitor, H-89, directly inhibits KATP and Kir channels in rabbit coronary arterial smooth muscle cells. Biochem Biophys Res Commun 340:1104-1110

42. Tallini YN, Ohkura M, Choi BR, Ji G, Imoto K, Doran R, Lee J, Plan P, Wilson J, Xin HB, Sanbe A, Gulick J, Mathai J, Robbins J, Salama G, Nakai J, Kotlikoff MI (2006) Imaging cellular signals in the heart in vivo: cardiac expression of the high-signal $\mathrm{Ca}^{2+}$ indicator GCaMP2. Proc Natl Acad Sci U S A 103:4753-4758

43. van Beugen BJ, Nagaraja RY, Hansel C (2006) Climbing fiberevoked endocannabinoid signaling heterosynaptically suppresses presynaptic cerebellar long-term potentiation. J Neurosci 26: 8289-8294 